\title{
POLA ASUH BALITA IBU-IBU KELOMPOK SASARAN \\ PADA PROGRAM KEGIATAN BINA KELUARGA BALITA USIA o-12 BULAN DUSUN GANDEKAN KARTASURA
}

\author{
Chatia Hastasari \\ Jurusan Ilmu Komunikasi Universitas Negeri Yogyakarta \\ chatiahastasari@gmail.com \\ Paramastu Titis Anggitya \\ Program Studi Ilmu Komunikasi Universitas Sahid Surakarta \\ erwinpurwasito@gmail.com \\ Anniez Rachmawati Musslifah \\ Program Studi Psikologi Universitas Sahid Surakarta \\ rachmawatianniez@gmail.com
}

\begin{abstract}
The rapid advancement of information technology was not enough to bring change in the attitude of the mothers in applying good parenting on their children. There are still many women who apply parenting capital only a myth or hereditary habits. The impact of the low level of understanding about parenting maternal age, especially toddlers 0-12 months of this should be a serious concern of all parties concerned, as stem from the application of good parenting toddlers that we can prepare the next generation of quality. The purpose of this study was to determine the parenting toddlers of mother target groups Program BKB aged o-12 months during which also evaluated from the perspective of communication. This study was designed using a "Research and Development". Results of this study when viewed from the perspective of communication, communication models on parenting toddlers applied by mothers of the target group in the success of the family development program of children aged 0-12 months are interactional model.
\end{abstract}

\begin{abstract}
Abstrak
Majunya teknologi informasi tidak cukup membawa perubahan dalam sikap ibu dalam menerapkan pola asuh yang baik bagi anak-anak mereka. Masih banyak wanita mengasuh berdasarkan "mitos" atau kebiasaan turun-temurun. Dampak dari rendahnya tingkat pemahaman tentang pengasuhan, terutama balita o-12 bulan ini harus menjadi perhatian serius dari semua pihak.Pasalnya, hal ini terkait dengan mempersiapkan generasi masa depan berkualitas. Tujuan dari penelitian ini adalah untuk menentukan pola pengasuhan balita kelompok sasaran Program BKB berusia 0-12 bulan yang dievaluasi dari perspektif komunikasi. Penelitian ini dirancang dengan menggunakan "Research and Development". Hasil penelitian ini adalah jika dilihat dari perspektif komunikasi, model komunikasi pada pengasuhan balita yang diterapkan oleh ibu dari kelompok sasaran keluarga anak usia 0-12 bulan adalah model interaksional.
\end{abstract}

Keywords: Interactional models, BKB Program, Parenting Toddlers. 


\section{PENDAHULUAN}

Rendahnya tingkat pemahaman ibu mengenai pola asuh balita saat ini dapat menjadi salah satu faktor yang membawa dampak buruk pada proses tumbuh kembang sang anak. Engle et al (1997) mengemukakan bahwa pola asuh meliputi 6 hal yaitu: (1) perhatian/dukungan ibu terhadap anak, (2) pemberian ASI atau makanan pendamping pada anak, (3) rangsangan psikososial terhadap anak, (4) persiapan dan penyimpanan makanan, (5) praktek kebersihan atau higiene dan sanitasi lingkungan dan (6) perawatan balita dalam keadaan sakit seperti pencari pelayanan kesehatan. Analisis antropometri data Susenas 1989- 1999 menunjukkan telah terjadi hambatan pertumbuhan bayi pada usia 4-6 bulan, baik di wilayah perkotaan maupun pedesaan (Jahari dkk, 2003).

Dari data tersebut dapat diketahui bahwa tingkat pengetahuan ibu terhadap pola asuh balita yang baik tidak dipengaruhi oleh tempat tinggal baik di kota maupun di pedesaan. Bahkan pesatnya kemajuan teknologi informasi saat ini (di mana para ibu dapat bergabung di komunitas dunia maya yang khusus membahas pola asuh balita) ternyata tidak cukup membawa perubahan sikap para ibu dalam menerapkan pola asuh yang baik pada balita mereka. Masih banyak para ibu yang menerapkan pola asuh hanya bermodal mitos atau kebiasaan turun temurun, misalnya pemberian MPASI dini. Orang tua jaman dahulu sudah memberikan makanan tambahan (MPASI) pada bayi saat berusia o-1 bulan. Seiring berkembangnya jaman, penelitian terkini menyatakan bahwa pemberian MPASI dini dapat menyebabkan gangguan pencernaan pada bayi. Namun demikian banyak dari ibu-ibu yang berada di desa masih memiliki keyakinan yang salah, yaitu memberikan MPASI dini pada bayi. Alasannya bayi yang baru lahir tidak cukup memperoleh gizi jika hanya dengan minum susu saja. (Hastasari dkk, 2013).

Program Posyandumemang bukan satusatunya tempat bagi para ibu memperoleh informasi mengenai pola asuh balita khususnya usia 0-12 bulan. Informasi tersebut dapat pula diperoleh dari program Bina Keluarga
Balita (BKB) yang ada pada tingkat Rukun Warga (RW). Namun, jalannya kegiatan tersebut ternyata tidak juga cukup efektif untuk meningkatkan kualitas pengetahuan ibu mengenai pola asuh balita. (Hastasari dkk, 2013). Pada program BKB misalnya, pemberian materi tidak bersifat permanen untuk dipelajari oleh para ibu yang menjadi kelompok sasaran. Karena memang pada program ini jarang sekali kader menggunakan modul sebagai media pembelajaran. Sehingga informasi yang diterima oleh para ibu hanya bersifat sementara bahkan tidak sampai pada penerapannya secara langsung.

Dampak dari rendahnya tingkat pemahaman ibu mengenai pola asuh balita khususnya usia dini o-12 bulan harus menjadi perhatian serius seluruh pihak yang terkait, karena bermula dari penerapan pola asuh balita yang baik inilah pemerintah dapat meminimalisir terjadinya gizi buruk dan penurunan kualitas generasi penerus bangsa. Maka dari itu penulis merasa perlu untuk melakukan sebuah penelitian mengenai pola asuh balita dari para ibu kelompok sasaran Program Bina Keluarga Balita usia o - 12 bulan selama ini yang juga ditinjau dari perspektif komunikasi

\section{Rumusan Masalah}

Adapun rumusan masalah dalam penelitian ini adalah:

1. Bagaimana pola asuh balita yang diterapkan oleh para ibu kelompok sasaran Program Bina Keluarga Balita usia o-12 bulan selama ini?

2. Bagaimana pola asuh balita dalam perspektif komunikasi?

\section{TINJAUAN PUSTAKA}

\section{Pola Asuh Balita}

Ritayani Lubis (2008) menyatakan pengasuhan berasal dari kata asuh (to rear) yang mempunyai makna menjaga, merawat dan mendidik anak yang masih kecil. Lain halnya dengan pendapat Whiting dan Child, menurut mereka dalam proses pengasuhan anak yang harus diperhatikan adalah orang- 
orang yang mengasuh dan cara penerapan larangan atau keharusan yang dipergunakan. Larangan maupun keharusan terhadap pola pengasuhan anak beraneka ragam. Tetapi pada prinsipnya cara pengasuhan anak mengandung sifat: pengajaran (instructing), pengganjaran (rewarding) dan pembujukan (inciting) (Sunarti, 1989).

Dari pemaparan di atas, dapat disimpulkan bahwa orang tua khususnya ibu memiliki unsur terpenting dalam penerapan pola asuh balita. Oleh karenanya, ibu harus selalu menambah dan membekali dirinya dengan pengetahuan-pengetahuan mengenai penerapan pola asuh balita yang baik. Hal ini penting dilakukan karena apapunlatar belakang pendidikan seorang wanita, ketika menjadi seorang ibu, mereka berangkat dari titik awal yang sama. Dengan demikian, sang ibu harus memiliki pengetahuan pola asuh yang baik pada anak sejak dini.

Kerangka konseptual yang dikemukakan oleh UNICEF yang dikembangkan lebih lanjut oleh Engle dkk (1997) menekankan bahwa tiga komponen yaitu makanan, kesehatan dan asuhan merupakan faktor-faktor yang berperan dalam menunjang pertumbuhan dan perkembangan anak yang optimal. Engle dkk (1997) mengemukakan bahwa pola asuh meliputi 6 hal yaitu: (1) perhatian/ dukungan ibu terhadap anak, (2) pemberian ASI atau makanan pendamping pada anak, (3) rangsangan psikososial terhadap anak, (4) persiapan dan penyimpanan makanan, (5) praktek kebersihan atau higiene dan sanitasi lingkungan dan (6) perawatan balita dalam keadaan sakit seperti pencari pelayanan kesehatan.Pemberian ASI dan makanan pendamping ASI pada anak serta persiapan dan penyimpanan makanan tercakup dalam praktek pemberian makanan. (Engle dkk, 1997).

Sayangnya kualitas pemahaman ibu terhadap pola asuh yang baik saat ini sangat rendah. Pengetahuan dalam hal pemberian ASI misalnya, Hastasari dkk (2013) menyatakan bahwa banyak ibu-ibu di kampung khususnya Dusun Gandekan, Kartasura masih meyakini bahwa kandungan susu formula juah lebih baik jika dibandingkan dengan kualitas ASI. Kenyataan yang sama juga ditemukan oleh Meliahsari dkk (2013) di lapangan, dihasil penelitiannya mereka menyatakan bahwa banyak dari anak yang walaupun disusui, juga masih dibantu dengan susu formula. Hal ini bisa terjadi karena pemberian ASI yang tidak baik saat pertama kali. Di samping itu, ada juga ibu yang terpaksa memberikan susu formula ketika anaknya baru lahir, karena ASInya belum keluar dan memberikan ASI hanya dalam beberapa minggu saja. Padahal susu formula dengan harga paling tinggi sekalipun tidak akan mungkin dapat menandingi keunggulan kandungan ASI. Sehingga pada usia di mana seharusnya bayi memperoleh ASI ekslusif, mereka justru memperoleh susu formula.

\section{Model Komunikasi}

Model adalah gambaran yang dirancang untuk mewakili kenyataan. Model adalah tiruan gejala yang akan diteliti. Model menggambarkan hubungan di antara variabelvariabel atau sifat-sifat atau komponen-komponengejala tersebut (Rakhmat, 1995). Model adalah representasi suatu fenomena, baik nyata maupun abstrak, dengan menonjolkan unsur-unsur terpenting fenomena tersebut. Model komunikasi bukanlah fenomena komunikasi itu sendiri, tetapi hanya alat tuntuk menjelaskan dan meredukssi fenomena komunikasi (Mulyana, 2005).

Model komunikasi adalah deskripsi ideal tentang apa yang dibutuhkan untuk terjadinya komunikasi. Dengan demikian secara sederhana, model komunikasi dapat diartikan sebagai gambaran tentang variabel-variabel atau komponen-komponen komunikasi, dan hubungan antara variabel-variabel atau komponen-komponen komunikasi tersebut.

Hingga saat ini, berbagai model komunikasi banyak dikembangkan dalam bidang kajian ilmu komunikasi. Namun, dari masing-masing model tersebut tidak kesemuanya efektif jika digunakan pada komunikator dan komunikan yang berbeda. Khairiyah (2008) menemukan bahwa model komunikasi wanita karier di Kelurahan Sidotopo Surabaya menggunakan model komunikasi S-R (Stimulus-Respon) terhadap anak bali- 
ta. Komunikasi terjadi pada saat ibu sedang mengasuh bayinya. Komunikasi membentuk aksi reaksi, ibu lebih aktif memberikan stimulus (rangsangan), sementara bayi/ anak berusaha memberikan respons (tanggapan). Komunikasi yang terjadi terhadap anak di atas usia 5 tahun mengikuti model komunikasi dua arah (two way communication). Yaitu, kedua belah pihak yang terlibat dalam komunikasi aktif dan kreatif dalam menciptakan arti terhadap ide atau gagasan yang disampaikan melalui pesan. Melalui hal tersebut jalannya komunikasi terkesan lebih dinamis dan komunikatif. Komunikasi model ini dilakukan secara tatap mukadan melalui penggunaan saluran komunikasi berupa telepon ataupun handphone.

Model komunikasi Tubbs menunjukkan suatu proses yang terjadi pada komunikasi pada umumnya, dimana ada komunikator/ source (pengirim pesan), adanya message (pesan yang disampaikan), dan adanya komunikan/receiver (penerima pesan). Komunikasi ini berupa verbal atau nonverbal. Komunikasi yang dilakukan merupakan komunikasi langsung secara tatap muka maupun melalui penggunaan saluran/channel berupa telepon rumah ataupun handphone dengan memanfaatkan pula fasilitas pesan tertulis (SMS) di handphone. Model selanjutnya menggunakan model komunikasi ABX, proses komunikasi yang berusaha dibangun antara suami-istri adalah komunikasi yang membutuhkan umpan balik (feedback). Topik pembicaraan yang dilakukan antara suami-istri adalah segala sesuatu yang berhubungan dengan keluarga seperti: masalah sandang dan pangan, pendidikan anak, pekerjaan di kantor dan sebagainya.

Intensitas pertemuan dengan suami maupun anak yang dilakukan oleh wanita karier dilakukan setiap hari. Selain hari kerja, hari Sabtu dan hari Minggu merupakan pilihan bagi mereka untuk dapat berkumpul bersama keluarga. Kebersamaan mereka dengan keluarga dapat menjalin komunikasi yang lebih efektif. Mereta tidak hanya membutuhkan waktu-kuantitatif--tetapi kualitas pertemuan yaitu bagaimana komunikasi dilakukan dengan baik.
Lain halnya dengan Heyan Pranata (2012) yang melakukan penelitian tentang model komunikasi interpersonal wanita karier dalam mewujudkan keluarga harmonis dan membina anak yang berkualitas di Perumahan Fajar Indah Surakarta. Hasil penelitiannyamenunjukkan bahwa terdapat dua model komunikasi interpersonal wanita karier dalam keluarga, yaitu model komunikasi interaksional dan model komunikasi ABX. Kedua model tersebut bertujuan untuk mewujudkan keluarga harmonis dan membina anak yang berkualitas.

Pengembangan dari penelitian mengenai model komunikasi yang terdahulu dengan penelitian yang dilakukan penulis saat ini, terletak pada fokus tujuan penelitian. Penelitian terdahulu mengenai model komunikasi memiliki tujuan untuk sekadar melakukan analisis, memaparkan atau mendeskripkan tentang model komunikasi yang telah digunakan oleh satu kelompok individu tertentu. Penelitian ini sampai pada tahap pengembangan modul pola asuh balita sebagai media pembelajaran untuk meningkatkan kualitas pengetahuan ibu-ibu kelompok sasaran dalam menunjang keberhasilan program bina keluarga balita usia 0-12 bulan.

\section{Program Bina Keluarga Balita Kelompok Usia o-12 Bulan}

Program Bina Keluarga Balitamerupakan suatu kegiatan penyuluhan kepada orang tua agar tetap memperhatikan perkembangan anak secara komprehensif bagi ibu-ibu yang memiliki balita dengan usia $\mathbf{0}-12$ bulan. Hastasari dkk (2013) dalam penelitian terdahulu menghasilkan model komunikasi pada program BKB kelompok usia o-12 bulan, berikut model komunikasi program BKB pada kelompok tersebut: 


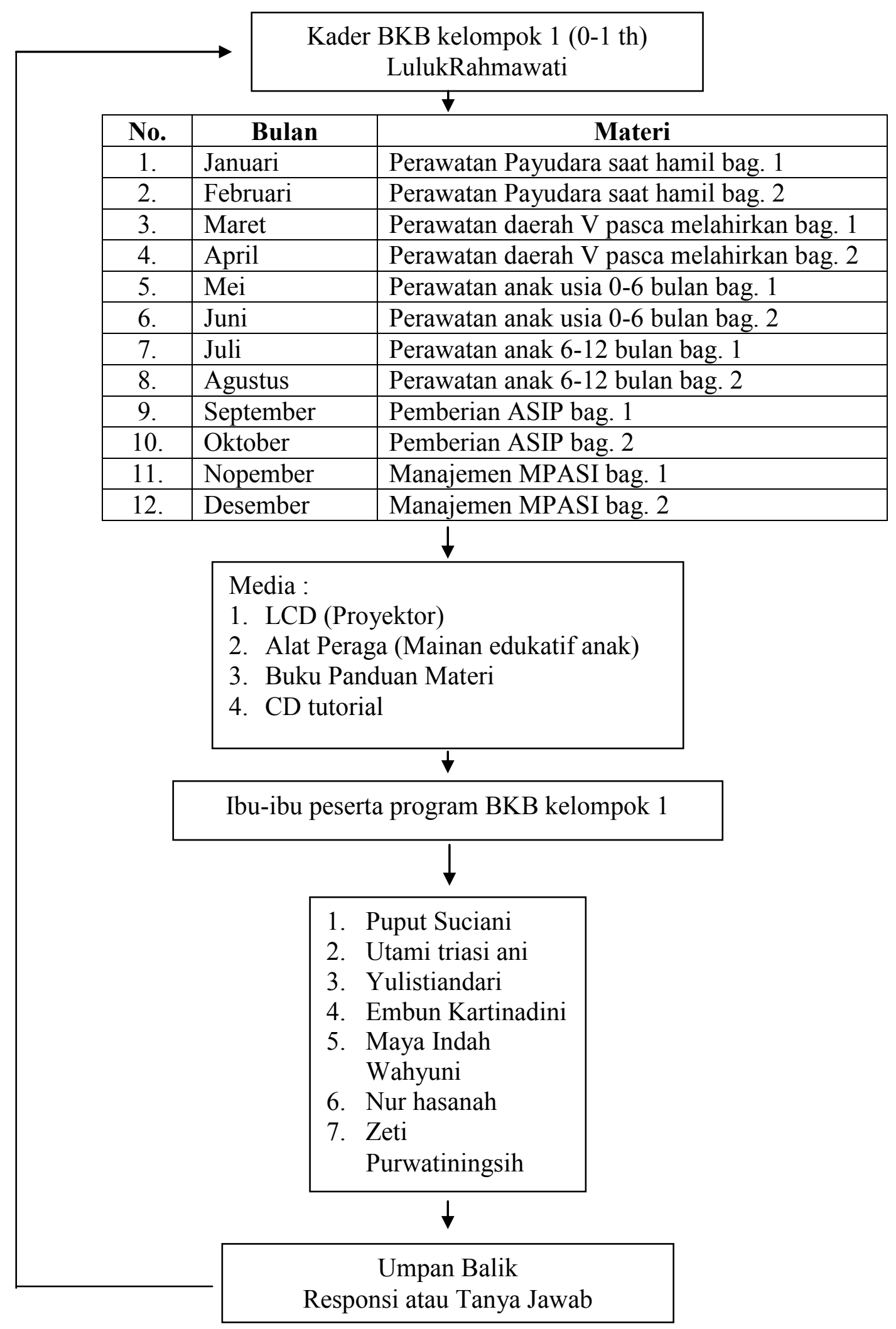

Sumber : Hastasari dkk (2013) 
Dari model komunikasi di atas, jelas terlihat bahwa peneliti terdahulu mendesain materi sesuai dengan usia yang dimiliki audiens mengenai pola asuh anak. Tujuan desain modul pola asuh balita ini adalah sebagai media pembelajaran untuk meningkatkan kualitas pengetahuan ibu-ibu kelompok sasaran dalam menunjang keberhasilan program Bina Keluarga Balita usia 0-12 bulan. masalah yang ada adalah bagaimana pola asuh balita yang diterapkan oleh para ibu kelompok sasaran Program Bina Keluarga Balita usia 0-12 bulan selama ini. (4) Peneliti menggunakan metode penelitian kualitatif melalui wawancara mendalam (depth interview) untuk memperoleh gambaran pola asuh balita yang diterapkan oleh para ibu kelompok sasaran. (4) Selanjutnya dengan analisis kualitatif akan disusun desainmodul

\section{Kerangka Berpikir}

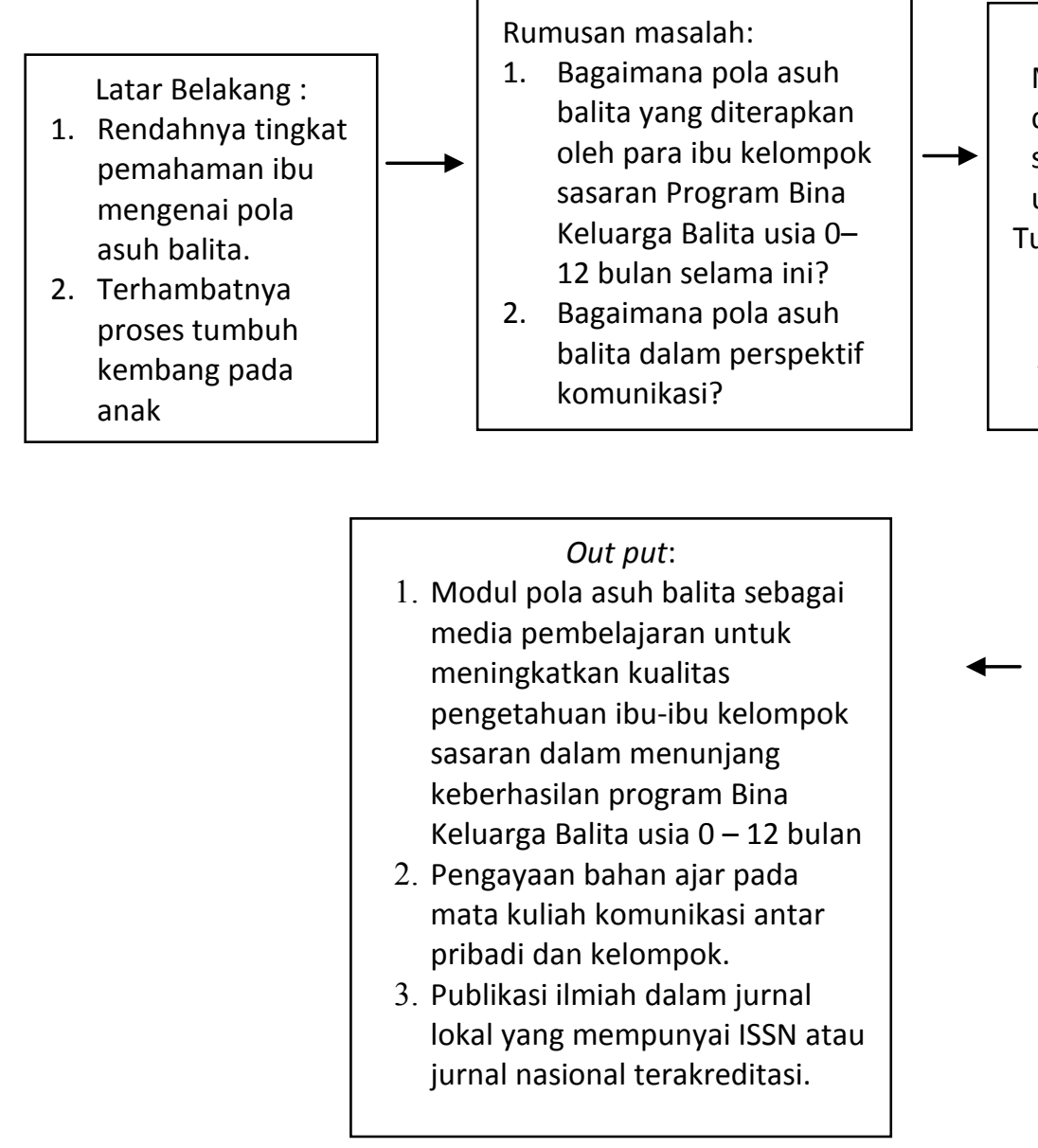

Tujuan umum:

Mengetahui pola asuh balita yang diterapkan oleh para ibu keompok sasaran Program Bina Keluarga Balita usia 012 bulan selama ini

Tujuan khusus:

1. Meningkatkan kualitas tumbuh kembang balita usia 0-12 bulan

2. Meningkatkan kualitas pengetahuan ibu-ibu kelompok sasaran.

\section{Gambar 1. Kerangka Berpikir}

Pada gambar 1, pokok-pokok pikiran yang melandasi perlu adanya pengembangan modul pola asuh balita sebagai media pembelajaran untuk meningkatkan kualitas pengetahuan ibu-ibu kelompok sasaran dalam menunjang keberhasilan program Bina Keluarga Balita usia o - 12 bulanadalah: (1) Rendahnya tingkat pemahaman ibu mengenai pola asuh balita saat ini. (2) Terhambatnya proses tumbuh kembang pada anak. (3) Berdasarkan gambaran ini, maka rumusan pola asuh balita sebagai media pembelajaran untuk meningkatkan kualitas pengetahuan ibu-ibu kelompok sasaran dalam menunjang keberhasilan program Bina Keluarga Balita usia 0-12 bulan, pengayaan bahan ajar pada mata kuliah komunikasi antarpribadi dan kelompok serta publikasi ilmiah dalam jurnal lokal yang mempunyai ISSN atau jurnal nasional terakreditasi. 


\section{METODE}

\section{Metode}

Berdasar pada target yang ingin dicapai, penelitian ini dirancang dengan pendekatan "Research and Development" artinya penelitian yang ditindaklanjuti dengan program pengembangan yang bertujuan untuk perbaikan ataupun penyempurnaan hasil penelitian. Sedangkan metode yang digunakan dalam penelitian ini adalahanalisis kualitatif. Riset kualitatif bertujuan untuk menjelaskan fenomena dengan sedalam-dalamnya melalui pengumpulan data sedalam-dalamnya (Kriyantono, 2008).

Penelitian ini menggunakan teknik purposive sampling. Sample dari penelitian yang berlokasi di Desa Pucangan Kecamatan Kartasura Kabupaten Sukoharjo ini berjumlah8 informan, di mana 7 informan diantaranya mewakili kelompok anggota BKB kelompok usia 0-12 bulan dan 1 informan mewakili kelompok kader BKB. Kedelapan informan yang mewakili masing-masing kelompoknya tersebut dikumpulkan dalam suatu forum FGD untuk memperoleh keseragaman data yang dibutuhkan dalam penelitian. Berikut 7 langkah dasar yang akan dilakukan oleh peneliti dalam pelaksanaan FGD menurut Pawito (2007):

1. Mendefisikan permasalahan yang sedang terjadi;

2. Menentukan sample berdasar teknik purposive sampling;

3. Menentukan jumlah kelompok. Kelompok yang akan diwakili oleh informan dalam penelitian ini berjumlah 2, antara lain: kelompok kader BKB dan ibu-ibu peserta program BKB kelompok usia o-12 bulan;

4. Menyiapkan pelaksanaan FGD. Langkah ini meliputi pembentukan panitia diskusi, penyiapan tempat, serta penyiapan alat;

5. Mempersiapkan materi diskusi. Peneliti akan membagikan kepada sejumlah peserta FGD copy materi yang telah dirumuskan;

6. Melaksanakan diskusi.

7. Menganalisis hasil diskusi. Analisis me- liputi codingterhadap sikap dan pendapat peserta yang sama, menentukan kesamaan sikap dan pendapat berdasarkan konteks yang berbeda, menentukan persamaan istilah yang digunakan, melakukan klasifikasi dan ketegorisasi terhadap sikap dan pendapat peserta FGD berdasarkan alur diskusi, mencari hubungan di antara masing-masing kategorisasi yang ada untuk menentukan gambaran hasil diskusi atau sikap dan pendapat kelompok terhadap fokus diskusi, menyiapkan draf laporan FGD untuk didiskusikan pada kelompok dosen sejawat sebelum diseminarkan dalam forum ilmiah.

\section{Teknik Pengumpulan Data}

Sebagai instrumen utama dalam penelitian kualitatif, peneliti berpartisipasi pada situasi riil, dan mendatangi subyek penelitian. Adapun teknik pengumpulan data yang dilakukan dalam penelitian ini antara lain:

Observasi, peneliti terjun langsung ke lapangan untuk melakukan pengamatan dan pencatatan mengenai pola asuh balita yang diterapkan oleh para ibu kelompok sasaran selama ini.

Interview atau wawancara mendalam, peneliti mendengarkan secara teliti dan mencatat apa yang akan dikemukakan oleh seluruh informan.Kajian isi dokumentasi, peneliti melihat kembali data-data dari dokumentasi berupa segala macam bentuk informasi yang berhubungan dengan penelitian yang dimaksud dalam bentuk tertulis atau mencari data mengenai hal-hal yang berupa buku petunjuk teknis BKKBN, catatan kader BKB, surat kabar, majalah dan sebagainya.

\section{Teknik Analisa Data}

Teknik analisis yang digunakan dalam penelitian ini adalah sebagai berikut:

Menelaah seluruh data yang tersedia dari berbagai sumber yaitu wawancara, pengamatan yang dituliskan dalam bentuk catatan lapangan, dokumen pribadi, dokumen resmi, dan lain sebagainya. 
Reduksi data. Pada tahap ini setelah data dipilih kemudian disederhanakan. Penyederhanaan ini memberi kemudahan dalam penampilan, penyajian, serta untuk menarik kesimpulan.Memeriksa keabsahan data, melakukan penafsiran data dalam mengolah hasil sementara menjadi teori substansif.

Penyajian data. Pada tahapan ini dilakukan pengorganisasian data kedalam suatu bentuk tertentu sehingga kelihatan jelas sosoknya lebih utuh. Data tersebut dipilah dan disisihkan menurut kelompoknya dan disusun sesuai dengan kategori yang sejenis untuk ditampilkan agar selaras dengan permasalahan yang dihadapi, termasuk kesimpulan-kesimpulan sementara yang diperoleh pada waktu data direduksi.

\section{HASIL DAN PEMBAHASAN}

\section{Karakteristik Informan}

Karakteristik informan dapat dilihat dari hasil wawancara yang meliputi umur ibu, tingkat pendidikan, pekerjaan dan jumlah anak balita. Hal ini dapat dilihat pada tabel berikut ini:

Tabel 1. Distribusi Informan Menurut Umur pada Ibu-Ibu Kelompok Sasaran Program BKB Usia 0-12 Bulan

\begin{tabular}{cccc}
\hline No. & Umur & N & \% \\
\hline 1. & $20-29$ tahun & 6 & $75 \%$ \\
\hline 2. & $30-40$ tahun & 2 & $25 \%$ \\
\hline
\end{tabular}

Sumber: Data Primer

Dari tabel 1 dapat diketahui bahwa distribusi informan yang tergabung dalam kelompok sasaran program BKB usia o-12 bulan yang terbanyak adalah ibu yang berumur 2029 tahun yaitu sebanyak 6 orang $(75 \%)$ dan yang paling sedikit adalah ibu yang berumur 30-40 tahun yaitu 2 orang (25\%).

Tabel 2. Distribusi Informan Menurut Tingkat Pendidikan pada Ibu-Ibu Kelompok

Sasaran Program BKB usia o-12 Bulan

\begin{tabular}{cccc}
\hline No. & Tingkat Pendidikan & $\mathbf{N}$ & $\mathbf{\%}$ \\
\hline 1. & Tidak Sekolah & 0 & $0 \%$ \\
\hline 2. & SD & 1 & $12.5 \%$ \\
\hline 3. & SMP & 0 & $0 \%$ \\
\hline 4. & SMA & 4 & $50 \%$ \\
\hline
\end{tabular}

\begin{tabular}{cccc}
\hline 5. & Akademi & 1 & $12.5 \%$ \\
\hline 6. & Strata 1 & 2 & $25 \%$ \\
\hline
\end{tabular}

Sumber: Data Primer

Dari tabel 2 dapat diketahui bahwa distribusi informan menurut tingkat pendidikan yang terbanyak adalah lulusan SMA yaitu sebanyak 4 orang (50\%).

Tabel 3. Distribusi Informan Menurut Pekerjaan pada Ibu-Ibu Kelompok Sasaran Program BKB usia o-12 Bulan

\begin{tabular}{cccc}
\hline No. & Pekerjaan & N & \% \\
\hline 1. & IRT & 5 & $62.5 \%$ \\
\hline 2. & Swasta & 3 & $37.5 \%$ \\
\hline
\end{tabular}

Sumber: Data Primer

Dari tabel 3 dapat diketahui bahwa distribusi informan menurut pekerjaan yang terbanyak adalah ibu yang bekerja sebagai IRT yaitu sebanyak 5 orang $(62.5 \%)$ dan yang paling sedikit adalah ibu yang bekerja sebagai karyawan swasta yaitu 3 orang (37.5\%).

Tabel 4. Distribusi Informan Menurut Jumlah Anak Balita yang dimiliki oleh Ibu-Ibu Kelompok Sasaran Program BKB usia o-12 Bulan

\begin{tabular}{cccc}
\hline No. & Jumlah Balita & N & \% \\
\hline 1. & 1 orang & 6 & $75 \%$ \\
\hline 2. & 2 orang & 2 & $25 \%$ \\
\hline
\end{tabular}

Sumbe : Data Primer

Dari tabel 4 dapat diketahui bahwa distribusi informan menurut jumlah balita yang terbanyak adalah ibu yang memiliki 1 anak balita yaitu sebanyak 6 orang $(75 \%)$ dan yang paling sedikit adalah ibu yang mempunyai 2 orang (25\%). Hal ini disebabkan karena sebagian besar ibu-ibu kelompok sasaran program BKB usia o-12 bulan merupakan ibu muda yang kisaran usia pernikahannya kurang lebih 2 tahun. (Hasil wawancara dengan ibu-ibu kelompok sasaran program Bina Keluarga Balita (BKB) usia o-12 bulan, 12 Mei 2014)

\section{Pola Asuh Balita yang Diterapkan oleh Para Ibu Kelompok Sasaran Program Bina Keluarga Balita (BKB) Usia o - 12 Bulan}

Dari hasil pengembangan kerangka kon- 
spetual UNICEF, Engle dkk (1997) mengemukakan bahwa pola asuh meliputi 6 hal yaitu:

1. Perhatian/Dukungan Ibu terhadap Anak dalam Praktek Pemberian Makanan.

Hasil penelitian menunjukkan bahwa sebagian besar ibu belum memiliki komitmen penuh dalam memberikan makanan sehat pada bayi mereka.Meskipun mereka telah memperoleh informasi baik dari tenaga kesehatan setempat maupun Kartu Menuju Sehat (KMS) terkait dengan praktek pemberian makanan yang baik pada bayi usia o-12 bulan. (Hasil wawancara dengan ibu Utami Triasi Ani, 12 Mei 2014).

Selain itu, penemuan di lapangan mengenai pola asuh berdasarkan perhatian/dukungan ibu terhadap anak dalam praktek pemberian makanan juga menunjukkan bahwa (1) Dalam hal pemberian ASI para ibu masih memberikan susu formula sebagai pelengkap, (2) Pemberian MPASI dini pada rentang usia 4-5 bulan, (3) Para ibu masih memberikan makanan instan sebagai makanan utama bayi, dan (4) Pemberian makanan selingan yang tidak sesuai dengan usia bayi (tempura, siomay, dan sosis goreng yang dijual di pinggir jalan). (Hasil wawancara dengan ibu Yulistiandari, 12 Mei 2014).

Namun demikian pengetahuan ibu mengenai kebersihan dalam menyiapkan makanan sudah baik. Hal ini dapat dilihat dari ibu yang selalu mencuci tangan sebelum mengolah, memasak hingga saat menyuapi bayi mereka dan mencuci alat makan sebelum dipakai. (Hasil wawancara dengan ibu Nur Hasanah, 12 Mei 2014).

Soenardi (2000) mengemukakan bahwa pada saat mempersiapkan makanan, kebersihan makanan dan peralatan yang dipakai harus mendapatkan perhatian khusus. Makanan yang kurang bersih dan sudah tercemar dapat menyebabkan diare atau kecacingan pada anak.

\section{Rangsangan Psikososial Terhadap Anak}

Hasil penelitian menunjukkan bahwa pola asuh ibu berdasarkan rangsangan psikososial terhadap anak sudah baik. Hal ini dapat diketahui dari kesediaan ibu untuk memberikan waktunya bermain dengan bayi mereka minimal 5 jam per hari-meskipun tiga diantara mereka merupakan ibu yang bekerja(Hasil wawancara dengan ibu Maya IndahWahyuni, 10 Juni 2014).

Soetjiningsih (1995) menyatakan bahwa anak memerlukan berbagai variasi permainan untuk kebutuhan fisik, mental dan perkembangan emosinya. Bermain bukan membuang-buang waktu, juga bukan berarti membuat anak menjadi sibuk sementara orangtuanya mengerjakan pekerjaannya sendiri. Bermain dengan anak memerlukan alat permainan yang sesuai dengan umur dan taraf perkembangannya.

Sedangkan pola asuh ibu berdasarkan rangsangan psikososial lainnya nampak pada keaktifan ibu dalam memerhatikan proses tumbuh kembang bayi, keaktifan ibu bercerita pada bayinya mengenai lingkungan sekitar (hewan dan tumbuhan), kesediaan ibu dalam menyediakan waktu untuk menyuapi sendiri bayi mereka dan kesabaran dalam memberikan pengertian melalui kata-kata saat bayi mereka melakukan kegiatan yang membahayakan. Sehingga bukan larangan yang mereka berikan saat mengetahui bayi mereka melakukan kegiatan berbahaya, namun lebih kepada memberikan pengertian. (Hasil wawancara dengan ibu Maya Indah Wahyuni, 10 Juni 2014).

\section{Perawatan Kesehatan}

Hasil penelitian dapat diketahui bahwa pola asuh ibu berdasarkan perawatan kesehatan sudah baik. Hal ini disebabkan karena sebagian besar ibu selalu memerhatikan kesehatan dan kebersihan anak serta kebersihan lingkungan. Hal ini dapat dilihat dari perilaku ibu yang selalu memerhatikan keterangan mengenai tumbuh kembang bayi di KMS (Kartu Menuju Sehat) sebagai pembanding tumbuh kembang bayi mereka, melakukan imunisasi lengkap dari usia o-12 bulan pada bayi mereka, memandikan bayi mereka dua kali sehari, dan selalu mencuci bersih badan bayi mereka sebelum menidurkan. Lingkungan di sekitar rumah juga terlihat bersih. (Hasil wawancara dengan ibu Nur Hasanah, 12 Mei 2014). 
Soetjiningsih (1995) mengemukakan bahwamasa balita sangat rentan terhadap penyakit seperti: flu, diare atau penyakit infeksi lainnya. Salah satu faktor yang mempermudah anak balita terserang penyakit adalah keadaan lingkungan. Oleh karena itu, lingkungan yang sehat perlu diupayakan dan dibiasakan tetapi tidak dilakukan sekaligus, harus perlahan-lahan dan terus menerus. Lingkungan sehat terkait dengan keadaan bersih, rapi dan teratur. Sehingga, anak perlu dilatih untuk mengembangkan sifat-sifat sehat seperti mandi, cuci tangan sebelum makan dan menyikat gigi (Sulistijani, 2001).

Namun demikian, meskipun pola asuh ibu berdasarkan perawatan kesehatan sudah baik, kesadaran ibu untuk rutin membawa bayi mereka ke Posyandu masih sangat rendah. Hal ini disebabkan karena beberapa faktor yaitu informasi mengenai jadwal Posyandu sering terlambat, cara penyampaian informasi dari tenaga kesehatan yang kurang tepat (menyinggung perasaan) sehingga mengurangi motivasi ibu-ibu kelompok sasaran dan jauhnya lokasi Posyandu. (Hasil wawancara dengan ibu Yulistiandari, 12 Mei 2014).

\section{Pola Asuh Balita dalam Prespektif Ko- munikasi}

Berdasarkan perilaku orang tua dan anak yang sering muncul dalam keluarga, pola komunikasi yang sering terjadi yaitu model komunikasi Tubbs, model interaksional, model stimulus-respon ( $\mathrm{S}-\mathrm{R}$ ), dan model ABX. Pada penelitian ini, model komunikasi pada pola asuh balita yang diterapkan oleh ibu-ibu kelompok sasaran dalam menunjang keberhasilan program bina keluarga balita usia 0-12 bulan adalah model interaksional. Penerapan model interaksional ini beraneka ragam bentuknya seperti:

1. Memperlihatkan kasih sayang non verbal, melalui praktek pemberian makanan.

Peranan ibu pada masa anak-anak besar sekali. Sejak dilahirkan, peranan tersebut tampak dengan nyata sekali, sehingga dapat dikatakan bahwa pada awal proses sosialisasi, seorang ibu mempunyai peranan yang besar sekali (bahkan lebih besar daripada seorang ayah). Peranan seorang ibu dalam membantu proses sosialisasi tersebut mengantarkan anak ke dalam sistem kehidupan sosial yang berstruktur. Anak diperkenalkan dengan kehidupan kelompok yang saling berhubungan dan saling ketergantungan dalam jalinan interaksi sosial (Rizka dalam Ayahbunda, 1999).

Berdasar hasil temuan di lapangan, dalam praktek pemberian makanan terjalin interaksi yang cukup baik antara sang ibu dengan balitanya. Hal ini sesuai dengan yang diungkapkan oleh Hinde (1976), interaksi dan waktu merupakan dua komponen mendasar bagi relasi orang tua-anak. Hinde juga menambahkan bahwa yang dimaksudkan dengan interaksi di sini adalah suatu rangkaian peristiwa ketika individu A menunjukkan suatu perilaku X kepada individu B.

Bentuk dari terjalinnya interaksi yang cukup baik antara sang ibu dan balitanya dapat dilihat dari kebersihan dalam menyiapkan makanan yang sudah baik yaitu mencuci tangan sebelum mengolah, memasak hingga saat menyuapi sang buah hati. Bentuk lainnya adalah sebagian dari ibu-ibu kelompok sasaran juga lebih memilih meluangkan waktu untuk memasakkan sendiri buah hatinya, seperti yang dipaparkan oleh Maya Indah Wahyuni (33 Tahun) berikut:

"kulo milih masak kiyambak mbak kangge lare-lare. Masak kiyambak niku liweh sehat...." (Hasil wawancara dengan ibu kelompok sasaran, 10 Juni 2014).

Namun berbeda dengan yang diungkapkan oleh Yulis (26 Tahun) berikut ini:

"yo sering tak tumbasne jajan-jajan pinggiran jalan mbak yen pas mlakumlaku neng manahan. Kadang yo anak'e dewe sing njaluk sosis, tempura. Njane kulo nggih ngerti mbak yen jajanan ngoten niku boten sae, tapi nggih pripun? Menawi boten dituruti, larene sok nangis kejer...." (Hasil wawancara dengan ibu kelompok sasaran, 12 Mei 2014). 
Dari pemaparan di atas, dapat diketahui bahwa meskipun dalam praktek pemberian makanan telah terjalin interaksi yang cukup baik antara sang ibu dengan balitanya, namun demikian belum sepenuhnya seluruh ibu-ibu kelompok sasaran memiliki komitmen yang kuat dalam memberikan makanan yang sehat.

2. Mengutamakan kualitas pertemuan.

Meskipun sebagian dari ibu-ibu kelompok sasaran merupakan ibu bekerja, namun mereka masih mengutamakan kualitas pertemuannya dengan sang buah hati. Berikut pernyataan dari Ibu Nana, salah satu ibu kelompok sasaran yang bekerja:

”...kalo saya mbakdari pulang kerja sampe malam, waktu itu untuk anak..." (Hasil wawancara dengan Ibu Nana, 23 November 2014).

Dari pernyataan tersebut, dapat diketahui bahwa kualitas pertemuan dengan anak masih sangat diutamakan. Aktivitas lain yang tampak dalam kualitas pertemuan ibu kelompok sasaran dengan buah hatinya adalah menemani balitanya mengenali lingkungan dengan aktif bercerita dan meluangkan waktu untuk menyuapi sendiri balitanya.

\section{Pesan Verbal}

Kegiatan komunikasi verbal secara langsung menempati frekuensi terbanyak dalam interaksi ibu kelompok sasaran dengan balitanya. Setiap hari ibu selalu ingin berbincang-bincang dengan anaknya. Canda dan tawa menyertai dialog antara orang tua dan anak. Perintah, suruhan, larangan, dan sebagainya merupakan alat pendidikan yang sering dipergunakan oleh orang tua atau anak dalam kegiatan komunikasi (Bungin, 2006).

Kegiatan komunikasi verbal yang dilakukan Luluk Rahmawati (30 tahun) adalah memberi pengertian pada sang anak saat melakukan kegiatan yang membahayakan. Berikut penuturan Luluk:

“...biasanya kalo siang ki anak sering bermain air di sekitar sumur mbak. Jadi saya seringnya kasih pengertian langsung kalo main di deket sumur itu berbahaya..." (Hasil wawancara dengan ibu kelompok sasaran, 25 November 2014).

Sedangkan kegiatan komunikasi verbal lainnya yang dilakukan oleh ibu-ibu kelompok sasaran pada buah hatinya adalah dengan selalu memberi pengertian pada sang buah hati untuk bisa berbagi mainan dengan teman sepermainan, mengajak berdo'a dan sholat bersama. (Hasil wawancara dengan Nur Hasanah dan Reny Wihastuti, 23 November 2014).

\section{Pembahasan}

Pengasuhan merupakan tanggung jawab utama orang tua, sehingga sungguh disayangkan bila pada masa kini masih ada orang yang menjalani peran orang tua tanpa kesadaran pengasuhan. (Lestari, 2012). Sebagaimana telah dipaparkan pada bagian sebelumnya mengenai bentuk pola asuh yang dilakukan oleh ibu-ibu kelompok sasaran Program BKB o-12 bulan bulan sudah memiliki kualitasyang cukup baik. Dikatakan cukup baik karena sebagian dari ibu-ibu kelompok sasaran masih belum memiliki komitmen penuh dalam beberapa hal tertentu, seperti pada saat praktek pemberian makanan pada buah hatinya. Hasil penelitian menunjukkan bahwa dalam hal pemberian ASI para ibu masih memberikan susu formula sebagai pelengkap, pemberian MPASI dini pada rentang usia 4-5 bulan, para ibu masih memberikan makanan instan sebagai makanan utama bayi, dan pemberian makanan selingan yang tidak sesuai dengan usia bayi (tempura, siomay, dan sosis goreng yang dijual di pinggir jalan).

Namun demikian untuk kualitas pemberian rangsangan psikososial dan perawatan kesehatan terhadap buah hati, sudah berjalan baik. Hal ini terlihat dari kesediaan ibu untuk memberikan waktunya bermain dengan bayi mereka minimal 5 jam perhari, keaktifan ibu dalam memerhatikan proses tumbuh kembang bayi, keaktifan ibu bercerita pada bayinya mengenai lingkungan sekitar (hewan dan tumbuhan), kesediaan ibu dalam menyediakan waktu untuk menyuapi sendiri bayi mereka dan kesabaran dalam 
memberikan pengertian melalui kata-kata saat bayi mereka melakukan kegiatan yang membahayakan-sehingga bukan larangan yang mereka berikan saat mengetahui bayi mereka melakukan kegiatan berbahaya- namun lebih kepada memberikan pengertian.

Sedangkan jika dilihat dari perspektif komunikasi, pola asuh ibu-ibu kelompok sasaran program BKB usia o-12 bulan cenderung mengarah pada komunikasi interaksional. Yaitu komunikasi dua arah, di mana terjadi dialog-dialog, percakapan yang membutuhkan umpan balik. Hal ini terlihat dari baiknya interaksi yang terjadi saat ibu mengolah masakan dan menyuapi sendiri buah hatinya. Sesuai dengan apa yang diungkapkan oleh Lestari (2012) bahwa dukungan orang tua mencerminkan ketanggapan orang tua atas kebutuhan anak merupakan hal yang penting bagi anak. Sehingga dengan mengolah dan menyuapi sendiri buah hati, maka kebutuhan balita akan kasih sayang seorang ibu dapat terpenuhi.

Bentuk komunikasi interaksional lainnya yang juga terjalin dengan baik adalah adanya kesediaan ibu dalam mengutamakan kualitas pertemuan dan melakukan komunikasi verbal secara langsung pada buah hati. Hal ini sesuai dengan apa yang diungkapkan oleh Paulson, Hill \& Holmbeck (1991) kedekatan merupakan aspek penting dalam kehangatan yang memprediksikan kepuasan pengasuhan dan keterlibatan anak dalam aktivitas keluarga(Lestari, 2012). Sehingga dengan adanya kedekatan ibu dan balita dalam bermain dan melaksanakan ibadah bersama dapat memberikan pengaruh yang positif terhadap perkembangan buah hati.

\section{SIMPULAN}

\section{Kesimpulan}

Berdasarkantemuan peneliti di lapangan mengenai pola asuh balita ibu-ibu kelompok sasaran program bina keluarga balita usia o-12 bulanyang dilakukan selama ini, dapat disimpulkan bahwa masih ada hal-hal yang perlu untuk diperbaiki. Adapun hal-hal yang masih membutuhkan perbaikan tersebut diantaranya adalah komitmen yang kuat dari ibu dalam memberikan makanan sehat pada bayi. Komitmen ini nantinya harus diwujudkan dalam pemberian ASI ekslusif 6 bulan dan dilanjutkan hingga usia bayi 2 tahun, pemberian MPASI pada bayi di usia 6 bulan, dan pemberian makanan alami sebagai makanan utama pada bayi.

Berangkat dari temuan tersebut, peneliti membuat desain pengembangan modul pola asuh balita sebagai media pembelajaran untuk meningkatkan kualitas pengetahuan ibu-ibu kelompok sasaran dalam menunjang keberhasilan program bina keluarga balita usia o-12 bulan. Diharapkan dengan adanya pengembangan modul ini dapat lebih meningkatkan kualitas pola asuh ibu pada bayi usia o-12 bulan, misalnya dalam hal:Permanent Reference, penjelasan-penjelasan mengenai materi yang ada dapat selalu mengingatkan ibu dalam menerapkan pola asuh yang baik pada bayi;Dengan penggunaan modul sebagai media pembelajaran dapat memudahkan kader program BKB untuk menyampaikan materi secara optimal;

\section{Saran} lah:

Adapun saran dalam penelitian ini ada-

Bagi ibu-ibu kelompok sasaran:

1. Hendaknya selalu mengikuti perkembangan pola asuh balita, baik dari social networking, kegiatan Posyandu dan dari informasi-informasi yang disampaikan oleh tenaga kesehatan setempat. Misalnya pemberian MPASI yang tidak lagi diberikan pada bayi usia 4 bulan melainkan 6 bulan.

2. Rutin mengikuti kegiatan Posyandu. Bagi Tenaga Kesehatan:

1. Melakukan evaluasi kehadiran ibu-ibu pada kegiatan Posyandu secara rutin.

2. Melakukan sosialisasi mengenai pola asuh balita yang baik. 


\section{DAFTAR PUSTAKA}

Azhar, Arsyad. 2011. Media Pembelajaran. Jakarta: PT. Raja Grafindo Persada.

Engle, P.L, Menon, P and Haddad, L, 1997. Care and Nutrition; Concept and Measurement. International Food Policy Research Institute

Hastasari, Chatia dan Perwita, Alvika Hening. 2013. Pengembangan Model Komunikasi Pelayanan Untuk Menghasilkan Kader yang Kreatif dalam Menunjang Keberhasilan Program Bina Keluarga Balita.

Kriyantoro, Rachmat. 20o8. Teknik Praktis Riset Komunikasi. Jakarta: Kencana Prenada Media Group.

Nasution, S. 2003. Berbagai Pendekatan dalam Proses Belajar dan Mengajar, Jakarta: Bumi Aksara.

Pawito. 2007. Penelitian Komunikasi Kualitatif. Yogyakarta: LKiS

Soenardi. T, 200o. Makanan untuk Tumbuh Kembang Bayi. Jakarta: Gramedia Pustaka Utama

Soetjiningsih, 1995. Tumbuh Kembang Anak. Jakarta: Penerbit Buku Kedokteran, EGC

Sulistijani, A.D. 2001. Menjaga Kesehatan Bayi dan Balita. Jakarta: Puspa Swara.

Sunarti, dkk. 1989.Pola Pengasuhan Anak secara Tradisional di Kelurahan Kebagusan Daerah Ibukota Jakarta. Depdikbud

Meliahsari, Renni, dkk. 2013. "Hubungan Pola Asuh Makan oleh Ibu Bukan Pekerja dengan Status Gizi Balita di Kecamatan Tongkuno Selatan Kabupaten Muna”. Jurnal Media Gizi Masyarakat Indonesia Vol. 2. No. 2, Februari 2013.Hlm. 113118.

\section{Sumber referensi lain}

Skripsi:

Lubis, Ritayani. 2008. "Hubungan Pola Asuh Ibu dengan Anak Balita di Wialayah Kerja Puskesmas Pantai Cermin Kecamatan Tanjung Pura Kabupaten Langkat Tahun 2008".Skripsi tidak diterbitkan. Fakultas Kesehatan Masyarakat Universitas Sumatera Utara.

Website:

Nurma Yunita dan Endang Susilowati. (Agustus 2010). Makalah Pengembangan Modul Surakarta: Lembaga Penelitian danPengabdianMasyarakat,Universitas Sebelas Maret. http://nurma.staff.uns. ac.id/files/2010/o8/teori-pengembangan-modul.doc.Unduh, 29 Januari 2012 pukul. 21.0o WIB.

Depdiknas. 2008. Pengembangan Bahan Ajar. Sosialisasi KTSP 2008. http:// d c218.4s hared.com/download / vj4M9KIo/5_PENGEMBANGAN_BAHAN_AJAR.rar?tsid=20120227-061731a8f2e27. Unduh, 29 Januari 2012 pukul 20.00 WIB. 
INFORMASI Kajian Ilmu Komunikasi Volume 45. Nomor 1. Juni 2015 